\title{
Critical literacy: The encounter between Western secularism and Islamic spirituality in selected young adult novels - An approach
}

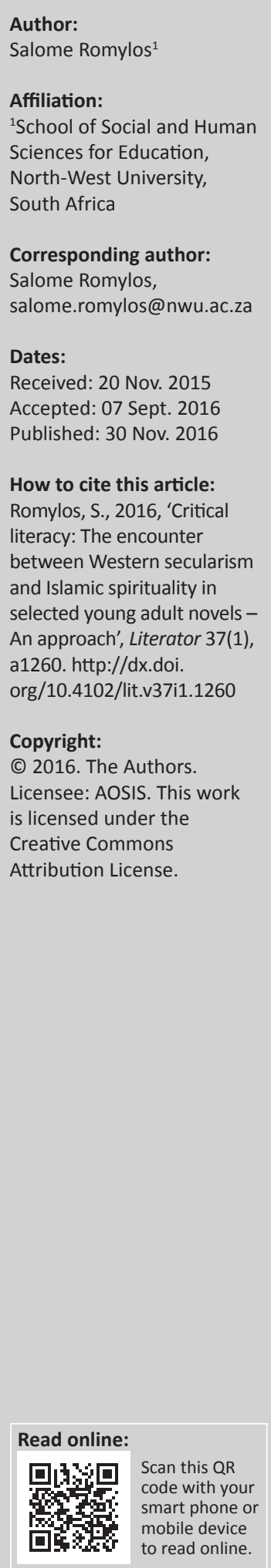

This article aims to show how selected young adult novels may be potentially powerful locations for creating an awareness and better understanding of Muslims, Islam, and veiling practices in particular. Critical literacy as a methodology will be employed to demonstrate how learners may be guided towards critically engaging with texts. This is essential as mere surface knowledge is not enough when learners are confronted with complex issues, such as race, spirituality and culture. Western TV, newspapers, and magazines are responsible for painting a very monolithic image of Muslims as a seamless homogeneous group. Many young adults are actively engaging in conversations on digital media, such as Twitter and Facebook, where issues of culture and diversity are commented on regularly. Westerners may form very negative perceptions of Islam and Muslims when inundated with a deluge of images of atrocities performed by extremist groups such as Islamic State of Iraq and the Levant (ISIL). The consequence is that all Muslims are stereotyped as being fundamentalists, terrorists and oppressing their women. Thus knowledge construction is manipulated by Western media. An understanding of the reasons for donning a piece of cloth - the headscarf - may serve as a starting point in changing perceptions about Muslims and their diverse practices. Educators should be wary of only advocating tolerance among different cultural groups, as tolerance implies a mere managing of one's feelings of aversion for that which is to be tolerated. Critical literacy questions on texts, such as The breadwinner trilogy by Deborah Ellis and The girl in the tangerine scarf by Mohja Kahf, are discussed as examples for use in classrooms. These texts are very different in their portrayals of Muslim girls/women and may be read comparatively. The complexity of the encounter between Western secularism and Islamic spirituality emerges either subtly or explicitly in the novels discussed.

Kritiese geletterdheid: Die ontmoeting tussen die Westerse sekularisme en Islamitiese spiritualiteit in geselekteerde romans vir jong volwasseness - 'n benadering. Hierdie artikel het ten doel om aan te toon dat die geselekteerde romans vir jong volwassenes potensieel kragtige ruimtes kan wees vir die skep van 'n bewustheid en beter begrip van Moslems, Islam, en veral van die dra van sluiers en kopdoeke. Kritiese geletterdheid as 'n metodologie word gebruik om te demonstreer hoe leerders gelei kan word om krities betrokke te raak by tekste. Dit is noodsaaklik, omdat blote oppervlakkennis nie genoeg is wanneer leerders gekonfronteer word met ingewikkelde kwessies soos ras, spiritualiteit en kultuur nie. Westerse televisie, koerante en tydskrifte skilder ' $n$ baie eensydige beeld van Moslems as 'n naatloos homogene groep. Baie jong volwassenes neem aktief deel aan gesprekke op digitale media, soos Twitter en Facebook, waar kwessies van kultuur en diversiteit gereeld ter sprake kom. Westerlinge kan baie negatiewe persepsies van Islam en Moslems vorm wanneer hulle oorval word met 'n stortvloed beelde van gruwelikhede wat uitgevoer word deur ekstremistegroepe soos die Islamitiese Staat van Irak en die Ooste (ISIS). Die gevolg is dat alle Moslems gestereotipeer word as fundamentaliste, terroriste en onderdrukkers van vroue. Hierdie kenniskonstruk word gemanipuleer deur die media. 'n Begrip van die redes waarom vroue 'n stuk lap - die kopdoek dra, kan'n beginpunt wees vir die verandering van persepsies van Moslems en hul verskillende praktyke. Opvoeders moet oppas om nie net verdraagsaamheid tussen verskillende kulturele groepe te verkondig nie, want verdraagsaamheid impliseer ' $n$ blote bestuur van 'n mens se gevoelens van afsku vir dit wat verdra word. Vrae wat uit'n standpunt van kritiese geletterdheid gestel kan word aan tekste soos The breadwinner-trilogie deur Deborah Ellis en The girl in the tangerine scarf by Mohja Kahf, word bespreek as voorbeelde wat in die klaskamer gebruik kan word. Hierdie tekste beeld Moslemvroue en -meisies baie anders uit en kan vergelykend gelees word. Die kompleksiteit van die ontmoeting tussen die Westerse sekularisme en Islamitiese spiritualiteit kom ook, subtiel of nadruklik, uit die romans na vore. 


\section{Introduction}

The young adult novels that will be discussed in this article focus on female characters, women and girls, their search for identity and their struggles to survive materially as well as psychologically. I argue that such young adult literature, which deals with aspects of Islamic culture, may be instrumental in helping readers gain a better understanding of Muslims and Islam, and particularly the treatment of Muslim women. Islam and its treatment of women are not a new point of contention (Al Qutami 2009), nor is the use of literature as agent in changing or enhancing perceptions (Baer \& Glasgow 2010). However, with the increased focus on the activities of Islamic fundamentalists in various parts of the world, such as Syria, Iraq, Afghanistan, Nigeria, Libya, and, more recently, parts of Europe, increased awareness of the diversity within Islam is necessary to avoid essentialised or monological representations of Muslims and Islam. Teenagers worldwide are bombarded by images in the media-authentic images - which may lead to stereotyping and general feelings of derision towards and fear of Muslims and Islam and the followers of this faith. These negative perceptions need to be discussed more regularly, as aspects, such as bigotry, faith or spirituality, freedom of speech, racial hatred, and violence against minority groups or people with different ideologies concern the global community. A critical literacy approach may be useful in guiding learners to look at knowledge construction critically. It is an instructional approach, in which learners are encouraged to read and critique texts and to question varying beliefs, values and attitudes prevalent in these texts. Critical literacy encourages readers to analyse texts, and offers strategies for uncovering underlying messages. According to Shor (1999), to be critically literate is 'to take a moral stand on the kind of just society and democratic education we want'. Shor (1999) postulates that this ethical stand was proposed many years ago by John Dewey, who emphasised that the cooperation between school and society must be based on collaboration, democratic relations, and equal distribution of resources and authority. Learners should be critical of, and question relations of power. How to employ critical literacy will be discussed in more detail in the 'Critical Pedagogy' section below.

The texts chosen for discussion of the portrayal of Muslims and Islam, and in particular women and the practice of veiling, are: Deborah Ellis's The breadwinner, Parvana's journey and Mud city, and Mohja Kahf's The girl in the tangerine scarf. These novels (Ellis's trilogy and Kahf's The girl in the tangerine scarf) differ in terms of complexity of plot, characterisation, diction and style. These novels are, however, useful in showing different representations of Muslims, and should preferably be taught comparatively as examples of multicultural texts. I aim to focus on the issue of veiling, as this issue is pertinent in the current sociopolitical climate and has been part of hegemonic and patriarchal discourse, specifically after the 9/11 incident (Alkarawi \& Bahar 2013; Martino \& Rezai-Rashti 2008; Toossi 2014). The 'hegemonic' order here references Western secularism's view that the Muslim veil is oppressive, and the term 'patriarchal discourse' points to Muslim men maintaining that the veil is the very symbol of Muslim piety, hence the insistence on Muslim women's bodies being covered either partly or wholly.

The issue of veiling and the divergent reasons for adhering to this practice may lead learners to a better understanding and critical awareness of the diversity within Muslim communities. Toossi (2014:641) is of the opinion that 'few religious clothing items and symbols can compete with the hijab (female Muslim head cover) and its power in eliciting strong and contrasting reactions in onlookers'. Najmabadi (2006:250) points out that 'the veil has a history far more complex and multilayered than its current signification with oppression or Islamic fundamentalism'. This complex and multilayered issue will be addressed in the section entitled 'The history and controversy around the Muslim veil'.

\section{The media and fundamentalist groups}

Since $9 / 11$, the representation of Muslims and Islam on TV, in newspapers, magazines and digital media has been less than flattering. However, this is not a new phenomenon: Edward Said, in Orientalism (1979), makes it very clear that Muslims, in general, have been portrayed as barbaric, backwards and in need of civilising by the West. Said's Orientalism (1979) is concerned with Orientalism and its relation to the history of colonial France and Britain, starting in the 18th Century, although criticism of Islam and Muslims has existed since at least the 9th century. Said (1997:58) in a later book, Covering Islam: how the media and the experts determine how we see the rest of the world, urges that one has to use the terms Islam and Islamic with constraint, as Islam has become 'a political cover for much that is not at all religious'. In other words, one has to qualify which and, for that matter, whose Islam one is referring to, as Islam has mistakenly become:

reducible to a small number of unchanging characteristics despite the appearance of contradictions and experiences of variety that seem on the surface to be as plentiful as those in the West. (Said 1997:11)

This article is also concerned with the fact that Islam is seen as a misogynistic religion by Western secularists, and the veil in its various forms is often seen as a symbol of oppression of Muslim women. Ameri (2008:1) states that Muslim narratives following the events of $9 / 11$ have 'reiterated the account of Islam as a backward and misogynist religion'. Ahmed (1992), in her book entitled Women and gender in Islam: historical roots of a modern debate (p. 35), contends that misogyny is not unique to Islam as a 'fierce misogyny' was rife in Mediterranean and Christian communities even before the rise of Islam in the 7th century. This may be true, but such arguments seem to relativise misogyny by arguing that it is not only endemic to Islam. 
Henry and Middleton Kaplan (2010:143), who are engaged in peace education, concur that in the aftermath of $9 / 11$, peace education is more 'visible and essential than ever'. It is irrefutable that radical Islamists are creating reigns of terror in places like Syria, Iraq, Afghanistan and Europe as a whole, where the self-proclaimed group ISIL ${ }^{1}$ has gained tremendous ground, as well as in Nigeria, where Boko Haram operates. Muslims and non-Muslims alike are victims of atrocious deeds of violence committed in the name of Islam. Extensive coverage of beheadings, suicide bombings and random killings of holiday-makers (Tunisia) have been shown. The atrocious attacks, aimed at French civilians on 13 November 2015 by assailants who included suicide bombers, are evidence that there is indeed a serious problem with Muslim extremists. Fareed Zakaria (2014), who writes a foreign affair column for The Washington Post, in an article entitled, 'Let's be honest, Islam has a problem right now', asserts that 'there is a cancer of extremism within Islam today'. He mentions statistics to back this statement: In 2013, 7 of the top 10 groups that were responsible for terrorist attacks were Muslim; the Pew Research Centre rated countries according to the restrictions they impose on freedom of religion, and of the 24 most restrictive countries, 19 are Muslim-majority; of the 21 countries that have laws against apostasy, all are Muslimmajority (2014). These statistics, and continual scenes of violence, contribute towards shaping Western ideas about Muslims and Islam, and viewers may form perceptions of Islam that are stereotypical. Viewers are bombarded with images of heavily armed gunmen at the back of vehicles, flaunting their weapons to the world. Particularly disturbing are images of those same radicals destroying ancient cultural artefacts, such as the Al-Arba'een Mosque in Tikrit, in September 2014; the Lion statue of Al-Lat in Palmyra, in January 2015, the 12th-century Mosque in Mosul, in February 2015, and the Temple of Bel in Palmyra, in August 2015, to name but a few. This destruction is deemed necessary by these vandals as many artefacts are, in their view, depictions of gods worshiped by 'infidels', instead of Allah.

The uttering of the words 'Allahu Akbar' (God is the greatest) just before killing some Christians or dissidents may lead non-members of these groups to equate ISIL, Al-Qaeda, Boko Haram and the Taliban with Islam. Islam has a following of 1.6 billion Muslims, and millions of them do not share the sentiments of these fundamentalist groups. Such onedimensional perceptions should be refuted to create a more realistic and truthful perception of Muslims and Islam. This article intends to show how literature, and specifically the novel, can be used to engage in a complex way with knowledge construction. Apple (1996:22) contends that knowledge construction is never neutral but is always part of a 'selective tradition, someone's selection, some group's vision' of what constitutes legitimate knowledge. The media is selective about what to show, and this selection is made by those in power. Plaisance (2002:5) mentions Michael

1.The Islamic State of Iraq and the Levant (ISIL) is also known as the Islamic State of Iraq and Syria (ISIS) and by its Arabic language acronym Daesh (a-Dawlah al-Islamiyah fial-Iraqwa-al-sham). Followers of this fundamentalist, jihadist, militant group adhere to an ultraconservative doctrine of Sunni Islam (Saltman \& Winter 2014).
Ignatieff's stance on a pluralistic philosophy for a global media: instead of dispatching daily images of atrocities and their consequences, the media should focus on explaining the causes of conflict. In other words, one may argue in Ignatieff's words that the rote transmission of emotional images and the satisfaction of having created moral disgust are no longer enough' to change perceptions that are ingrained through repetition. The reading of literary texts may help fulfil this missed opportunity by the media to examine causes and the complex issues surrounding conflict. It is the responsibility of teachers to prepare learners adequately as thinking, proactive agents of change. I elect to use phrases such as 'the understanding of Islam', and specifically 'veiling practices', instead of the term 'tolerance', but would like to examine the notion of tolerance and its limitations in trying to bring about change in racial, cultural and spiritual perceptions.

\section{Tolerance: An ambivalent term}

The word 'tolerance' is derived from the Latin word 'tolerantia' (tolerate, bear and endure). Tolerance is defined in the online Oxford English Dictionary (OED 2015) as:

The action or practice of tolerating; toleration; the disposition to be patient with or indulgent to the opinions or practices of others; freedom from bigotry or undue severity in judging the conduct of others; forbearance; catholicity of spirit.

Brown (2008:30-31) informs us that the Reformation introduced this doctrine of tolerance, and many thinkers of that time (Baruch Spinoza, John Milton, Gotthold Ephraim Lessing and John Goodwin) among others wrote about this doctrine of tolerance. During the post-reformation, John Locke, ironically while in exile in the Netherlands, pleaded in his 'Letter Concerning Toleration' (published in 1689) not only for religious toleration but also for a definite separation of church and state. The inability of certain nations to separate church and state is a major contributing factor of those nations being seen as intolerant by the West. Of course, the West also does not have a clean record as far as intolerant practices are concerned. Brown (2008:37) mentions the Crusades, the Spanish Inquisition, the Puritans' witch hunts, anti-Semitism, the slave trade and genocide, as examples. It is not my intention to create binaries such as the West versus the East, or to determine who is guiltier of atrocities but to show how tolerance can be misconstrued when considered from a one-sided point of view.

Nieto (2010:247) maintains that tolerance is 'a word commonly used when speaking about appropriate responses to difference'. She sees tolerance on its own as ineffective in encouraging diversity. Brown (2008:25) argues that the term tolerance seems to be pacific but blends together 'goodness, capaciousness, and conciliation with discomfort, judgment and aversion'. Brown (2008:5), in her book entitled Regulating aversion: tolerance in the age of identity and power, postulates that tolerance involves 'managing the presence of the undesirable, the tasteless, the faulty - even the revolting, repugnant, or vile'. Thus, she supports the argument that 
tolerance may be inadequate as it does not necessarily lead to a solution but is 'only a strategy for coping'. She maintains that in the aftermath of September 11, the enemy of tolerance is now the 'weaponized radical Islamicist state or terror cell' (Brown 2008:6). Where Nieto urges that respect should accompany tolerance, Brown believes that definitions of tolerance make it clear that there is no neutrality or respect for what needs to be tolerated. In other words, to tolerate is far from understanding and respecting. Tolerance implies an ambivalent reaction to someone or something, involving both an attraction and repulsion, which translates into an obligation to tolerate, but simultaneously a repulsion for that which is to be tolerated. Tolerance is often seen, in educational environments, as a panacea for problems involving cultural, racial and spiritual issues.

Many schools approach tolerance of multiculturalism or diversity through superficial 'culture days', when there is a focus on culinary products and dress, as well as through observing ethnic holidays. These approaches offer a very limited understanding of diversity. Nieto (2010:67) maintains that if multicultural education includes only the formerly mentioned aspects, prospects for substantial change are meagre. She mentions seven characteristics of multicultural education, but for purposes of this article I will concentrate on multicultural education in relation to anti-racism, critical pedagogy and social justice (Nieto 2010:68).

\section{Critical pedagogy}

Paulo Freire (1921-1997) is considered the founder of critical pedagogy. Critical pedagogy has as goal the preparation of learners to play an active role in democratic societies. The purpose of education, through this approach, is to redress inequality and to transform society. That means that all voices should be heard and given an equal platform. These ideals are closely linked to the ideals of multicultural education, whose approach 'values diversity and encourages critical thinking, reflection and action' (Nieto 2010:80). For purposes of this article, critical literacy (where the focus is more on language), which is a branch of critical pedagogy, will be used in the textual analysis to follow. Learners should move beyond shallow interpretations of texts and become aware of the hidden agendas in them. Lewison, Flint and Van Sluys (2002:282) identify the four dimensions of critical literacy as: 'disrupting the commonplace; interrogating multiple viewpoints; focusing on sociopolitical issues, and taking action and promoting social justice'. The usual recipe of discussions concerning plot, setting, theme, character and focalisation are insufficient in facilitating a deeper understanding of crucial social issues. Learners should be guided to question issues of culture, race, ethnicity, gender and spirituality, and how these are connected to power in societies. McLaren (2009:9) observes that knowledge is a social construction that is deeply enmeshed in a 'nexus of power relations'. Questions such as whose views are portrayed, how and by whom, what is included and what has been omitted, should be addressed. It is evident from the ideals of critical pedagogy and literacy that one needs to move beyond mere tolerance in order to effect change.

Nieto (2010) maintains that acceptance, respect, affirmation, solidarity and critique are needed to move beyond tolerance. Acceptance of 'the other' does not necessarily imply endorsement, but an understanding that others are different. It should be clear to learners that this can oftentimes be uncomfortable and painful, as sensitive issues will be discussed, which may even lead to conflict. Reflecting about and taking a critical stance towards one's own culture is necessary to be able to understand other cultures. DeanRuzicka (2012) also believes that tolerance does not suffice, as she maintains that tolerance merely asks us not to act upon feelings of hatred and resentment. What is needed is to examine what leads to hatred and resentment, echoing Ignatieff (2002) when he pleads for explanation by the press, rather than consequences. Dean-Ruzicka (2012:199) argues that young adult literature can be instrumental in helping learners 'look beyond tolerance towards a cosmopolitan ethics of difference as a more sophisticated position for combating hatred'. A 'sophisticated position' can be reached by critically engaging with complex issues. Many educators may feel hesitant to discuss sensitive issues such as culture, race, gender and spirituality, but avoidance of such issues will not make them disappear.

\section{Teaching implications}

The teaching implications of the discourse on tolerance are that learners are made aware of cultural assumptions and different perceptions to evaluate media coverage and representation of cultural groups in novels. The novel is a functional vehicle to teach learners about multiculturalism, and its efficacy lies in the fact that such teaching may be done subtly and not explicitly, while at the same time providing ample opportunity for critical evaluation and reflection. Lynch-Brown, Tomlinson and Short (2014:4) assert that empathy for those who are restricted by their disabilities, politics or circumstances, or whose lives are different from the readers, may be evoked through the novel. Nodelman and Reimer (2003:156) argue that learners should read 'against the text'. In other words, learners should notice absences in a text and should question the ideologies that are implied by them. Learners should not be subconsciously persuaded that what is presented in a novel is the only truth. At this point, it is necessary to take a look at the history of the veil and veiling practices.

\section{The history of the veil and perceptions from both a Western secular and Islamic spiritual epistemology}

As mentioned earlier in the article, the Muslim veil has occasioned controversy for many years. Recently, it was at the centre of a debate in Canada, initiated by Stephen Harper, as to whether the niqab (a veil covering all of the face of a 
woman except the eyes) may be worn by women when they are sworn in for citizenship. In South Africa, a 13-year old Muslim girl was ordered to remove her headscarf as it was contrary to the school rules (Rondganger \& Govender 2004:3). Many argue that the oppression of women in Afghanistan provided a reason and justification for the US military invasion of and intervention in Afghanistan in October 2001 (Aaftaab 2005; Abulughod 2000). The words of former First Lady Laura Bush make this clear: 'Because of our military gains in Afghanistan, women are no longer imprisoned at home' (The Washington Post 2001). In other words, veiling practices were indirectly responsible for the military intervention, as veiling practices are seen as being symptomatic of Islamic oppression of women, according to many Westerners. This argument may seem syllogistic, but it is partly true.

According to Hoodfar (2003), the veil now features as a political tool used by the media to highlight the oppression of Muslim women in a patriarchal society. This negative emphasis on the veil as indicating the oppression of women leads to a limited understanding of it. Many learners from Western backgrounds will never be enlightened about the diverse reasons for veiling by Muslim women. Ahmed (2005:164) comments on the reasons why Muslim women veil, and asserts that the reasons are 'as varied, multiple, complex, and shifting [...] as are the women themselves'. The fact that veiling is a choice for some and not a coercive response is hardly considered by those ignorant of the practice.

Understanding the multiple significations of the veil as a spiritual/personal as well as national/political symbol may help in making learners conscious of the diversity within Muslim societies, and may change simplistic perceptions of Muslims being a seamlessly integrated cultural and spiritual group. Taught about the history of the veil, learners may be surprised to hear that veiling practices did not originate in Islamic society. Cultures influence one another, a fact that Said (1993:xxix) reiterates: '[...] all cultures are involved in one another, none is single and pure, all are hybrid, heterogeneous, extraordinarily differentiated, and unmonolithic'. The rules specifying who had to adhere to the practice of veiling and who not are carefully explained in archaic Assyrian Law (Ahmed 1992:14). The Hammurabi law codes of 1752 BCE contain the first references to the virtue of women being secluded and protected. Not all women were expected to veil: spouses and daughters of noble men, concubines, former prostitutes (now married) had to veil, whereas prostitutes and slaves were prohibited from being veiled. Those who veiled illegally suffered serious consequences, such as having their heads covered in pitch or their ears ripped off. The practice distinguished respectable women from those available to men (Ahmed 1992:14-15). Ahmed (1992:15) concurs that the veil categorised women according to their sexual activity, and indicated to men which women were protected by other males and which were not. Learners may be made to consider whether a veil necessarily protects a woman from sexual predators. Hoodfar (2003:6) observes that the veil was never seen as an exclusive symbol of Muslim culture before the 19th century; the practice of veiling originated in pre-Islamic, non-Arab Middle-Eastern and also Mediterranean cultures. She continues to say that veiling especially when coupled with inaccessibility - was indicative of status and privilege in ancient Greco-Roman, pre-Islamic Iranian, and Byzantine societies (Hoodfar 2003:6). Woodlock (2000) asserts that Ahmed fails to mention that the Prophet Mohammed oftentimes took existing pagan rituals and incorporated those into Islam with entirely new meanings. However, the fact that not just Muslim societies insisted on the wearing of the veil, does not make it less oppressive to some women. What Ahmed (1992) and Hoodfar (2003) explain is that a woman's moral value and worth are determined by male patriarchy. Nina Hoel (2013) sees this notion of males being the protectors and maintainers of women in the Qur'an, as strengthening patriarchal understandings and thus 'rendering gender asymmetry normative and religiously appropriate'.

El Guindi (cited in Woodlock 2000) poses that one should move beyond questions of what the veil is, who engages in this practice, and whether or not veiling originated in Islamic culture. The issue should rather centre on the meaning of the veil in diverse historical and cultural contexts. El Guindi further points out that just as Muslims convert ordinary space into temporary sacred space (praying in public), Muslim women take their private space into public space when they veil themselves. Mazumdar (2001) explains that these spaces are not seen as inherently public or private, but it depends on whom one is interacting with in these spaces. 'Mahram' includes members of the opposite sex with whom marriage is explicitly forbidden (for a man: mother and sister and for a woman: father and brother), whereas 'na-mahram' includes members of the opposite sex with whom marriage is allowed. This implies that both men and women should adhere to certain restrictions regarding interaction with the opposite sex. Women wanting to move into a public space where the possibility exists to meet members of the Namahram should therefore be accompanied by a male family member and be veiled. Mernissi (cited in Wise 2009) maintains that:

Reducing or assimilating this concept [veil] to a scrap of cloth that men have imposed on women to veil them when they go into the street is truly to impoverish this term, not to say to drain it of its meaning. (p. 95)

Therefore, Muslim feminists insist on not seeing the practice of veiling as either an imposition or a sign of modesty, but fundamentally as a choice. It is this very notion of choice that many Western secularists fail to comprehend.

Bouleanu (2013) explores Muslim feminists, Mernissi, Saadawi and Wadud's notions regarding the wearing of the veil. Mernissi touches on the issue of change in Muslim societies, and the fact that some see change as immoral. Bouleanu (2013) concurs that Mernissi sees unveiling as 
belonging to this type. Many Muslim women point to the spiritual significance of the veil found in certain interpretations of Quranic texts, for example, the 24th chapter of the SurahAn-Nur, verses 30-31:

And tell the believing woman to lower her gaze and be modest, and to display of their adornment only that which is apparent, and to draw their veils over their bosoms, and not to reveal their adornment save to their own husbands or fathers or husbands' fathers.

Saadawi (cited in Bouleanu 2013) argues against placing undue emphasis on the issue of veiling and she dissipates the notion that veiling of women is regarded as the epitome of Islamic feminism. This assertion does an injustice to the Muslim women as it trivialises a complex issue. Wadud affirms that the debate around the veil is oversimplified and results in stereotyping. She adds that this perception of a veiled woman as a sexually oppressed victim of male patriarchy is not beneficial to feminism but reinforces the sexual simplification of women. Those in favour of the veil for providing protection and signalling respect further fuel this sexual simplification of women. She believes that men, who want to objectify women sexually, will do so regardless of whether they are veiled or not. Hoel (2013) argues that assumptions about women's sexuality and the necessity to conceal it, pose questions about men's ability for sexual selfcontrol and 'signals a fragile spiritual self'. These arguments by Muslim feminists all point towards personal choice that should be the determining factor in whether a woman wants to be veiled or not. The next section will provide a brief overview of the texts discussed before engaging with critical literacy questions. The aim of the critical literacy questions is to provide examples of how learners may be challenged to look at texts critically and to delve deeper into knowledge construction.

\section{The breadwinner (2000), Parvana's journey (2002) and Mud city (2003) by Deborah Ellis}

Deborah Ellis wrote this trilogy with 12-year-old Parvana as the main character who lives under the regime of the Taliban in Afghanistan. Her father is arrested because he has been educated in the West. Parvana's brother died in a landmine accident, but she still has two sisters. She agrees, reluctantly at first, to support her family as breadwinner, as there is no male member of her family left to do so, and the Taliban forbid women or girls to roam the streets unaccompanied by a male member of the family. She disguises herself as a boy by cutting her hair and wearing her dead brother's clothes. After her father died she has to travel across Afghanistan to find her mother and other siblings. Mud city, the sequel to Parvana's journey, is about Shauzia, Parvana's one time class mate, who escapes her miserable life in Kabul, and who ends up in a refugee camp in Pakistan. Shauzia eventually postpones her dreams of going to France and the imaginary lavender field in order to offer her help to displaced women and children just when the US attacks Afghanistan.
These novels are suitable for learners aged 12-16 and may be used to teach about current events in Afghanistan, survival, friendship and family values. Ellis is a Canadian writer who has travelled to refugee camps to interview many Afghani girls and women, and she bases her novels on the stories of these girls and women. Although Ellis has been praised for her excellent raising of awareness about the desperate plight of women and girls in Afghanistan, she has also been criticised for relying on colonial discourses when portraying third-world girls and women as backwards, uneducated, constrained and in desperate need to be rescued by the West (Sensoy \& Marshall 2009, 2010). One has to keep in mind that the trilogy is set in a very specific time frame and setting, namely Afghanistan under the Taliban regime that took control of Kabul in September 1996. Under this regime, girls and women were without a doubt constrained and poor. It cannot be denied that girls and women were (and still are) treated atrociously by militant fundamentalists (Taliban) in Afghanistan. Khan et al. (2007:390) concur that the focus placed by Ellis on the restrictiveness of the burqa raises doubts about Ellis's understanding of traditional Muslim cultures. Being Canadian, Ellis necessarily writes from a Western point of view, although she has first-hand experience of life in Afghanistan. Learners may be prompted to discuss whether a non-native author can legitimately be an expert on the cultural ways of others. Some learners may argue that novels about Muslim girls, written by white women, are used by the West to strengthen the idea that Muslim women are oppressed, and moreover that this oppression is endorsed by Islam. Nodelman and Reimer (2003:175) concur that those who object to writers depicting the experiences of those from another cultural group, call it 'theft' or 'cultural appropriation'. However, other learners may argue that personal experience and research are enough to portray an authentic image of a culture different from one's own.

Critical literacy questions on many aspects in the trilogy may be asked. In what follows, I offer a few such questions, along with examples of how they may be asked.

\section{The portrayal of Muslim girls - clash between Western secular values and Islamic culture}

Mud city features the well-known image of Sharbat Gula on the book cover, taken originally in 1985 by journalist Steve McCurry, and which appeared on the cover of National Geographic in the same year. After 17 years of searching for the girl, her identity was revealed. Learners may be prompted to ponder why she looks frightened. Hesford and Kozol (2005:6) assert that the image of the girl's 'apparent beauty and innocence appeals to Western viewers' sensibilities about who deserves and needs rescue'. Learners should consider the intention of the image, the emotions evoked by it and the accuracy of representation. It may be assumed by Western readers that the girl is too traumatised by the atrocities of the Taliban to speak, while ignoring the fact that she may be shying away from a Western man taking her photograph. 
That the girl's mouth is covered by the veil could be interpreted by Western secularists as a subtle suggestion of her not having a voice of her own.

On the first page of The breadwinner, Parvana mentions that she is not allowed to be heard in public: 'The man sitting beside her father would not want to hear her voice. Nor would anyone else in the Kabul market' (Ellis 2000). Parvana points to the belief of some Muslims that a female's voice should not be heard by mahram (those with whom marriage is allowed). Hoel (2013:31-32) enlightens her readers about the reasons given by the Muslim Judicial Council for having objected to Amina Wadud giving a sermon in a Cape Town mosque in 1994 to a mixed congregation. Their main point of criticism relates to the 'awrah' (nakedness) of a woman's voice. The 'Qur'anic verse 33:32, where God requests the wives of the Prophet to pay particular attention to their speech in public places, so as not to lead men into lustful thoughts, is given as justification for the silencing of women in public spaces. This 'awrah' also applies to women's bodies and requirements of modesty. Hoel (2013:32) observes that by implication a woman's modesty depends on her 'ability to conceal her body and voice'. Learners may consider how a woman's body being concealed is a signifier of modesty or devoutness. Questions such as how one can be unveiled as a Muslim and still be devout may be posed.

On one copy of The breadwinner, the following words appear:

Imagine living in a country in which women and girls are not allowed to leave the house without a man. Imagine having to wear clothes that cover every part of your body, including your face, whenever you go out. (Ellis 2000)

The word 'imagine' implies a sense of the unthinkable, thus strengthening negative Western perceptions. The fact that the wearing of the veil in certain instances constitutes a deliberate rejection of Western values, should also be pondered on and examples may be given. One such example that may be explored by learners is the 1936 ban of the veil in Iran under the regime of Reza Shah, which many women opposed. Kemal Ataturk, the first president of Turkey (1925-1938) introduced a series of dress regulations banning the wearing of religious symbols from the civil service. This ban was enforced in the 1980s but was lifted in 2013 because of pressure from women who insisted on wearing the veil for religious reasons. Wearing the veil signals pride in their faith for some Muslims, especially when Islam is under attack from non-Muslims. Bean and Harper (2006:99) observe that although this outright rejection of Western values is omitted in The breadwinner, the focus of the novel on the rigid restrictions on women's lives is fundamental in comprehending the 'nature of external freedom'. Parvana questions her father about women wearing the burqa in The breadwinner: 'How do women in burqas manage to walk

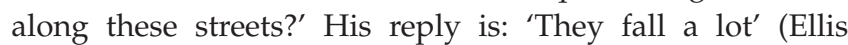
2000:11). Nooria, Parvana's sister, tells Parvana that she is going to throw off her burqa and tear it into a million pieces (Ellis 2000:133). These words echo a Western perception of veiling as restrictive and unnecessary. Parvana cross-dresses to be able to roam the streets. She shows remarkable courage and an altruistic attitude when agreeing to become a boy. On a practical level, there was not much of a choice for Parvana. This does not, however, mean that Parvana completely rejected the sartorial ways of Muslim womanhood, nor is there evidence in the novel of such a complete rejection. This choice of disguising herself as a boy is purely a survival strategy. An alternative solution may provide for an excellent class discussion. Learners may ponder on issues of representation and whether Ellis's portrayal of Muslim girls may be problematic to Muslim girls in particular. Such narration may result in some Muslim girls questioning veiling practices, or in some being confused about whether they are indeed in need of civilising. In other words, having doubts about one's cultural practices may result in cultural alienation.

\section{Whose stories are told and whose are omitted?}

Mrs. Weera is the representative of spirited and tenacious Afghani women who are determined to make a difference in the lives of women. She features prominently in Mud city. She is actively involved in organising secret schools, clinics and a magazine. She is a resourceful woman and at one stage the reader learns that she 'swept into the compound like a strong wind' (Ellis 2003:12). She guides Shauzia towards adopting a more altruistic approach to life. Shauzia dreams of a distant utopian France and a lavender field, but fails to realise that she can be more useful to her own people. Mrs. Weera is practical in her approach:

In a few years, you might be able to work as a nursing assistant and earn more money that way. The sea isn't going anywhere. Neither, as far as I know is France. (Ellis 2003:14)

Mrs Weera is not shocked when she hears about Parvana and Shauzia digging up the bones in a cemetery as a means of providing for their families: 'These are unusual times. They call for ordinary people to do unusual things, just to get by'. She represents one who believes that society's welfare should be considered above that of the individual: 'Do you mean to say she would just leave her family? Desert the team just because the game is rough?' (Ellis 2000:155). Learners growing up in societies endorsing individualism may be in favour of Shauzia longing for a better life for herself in contrast to those from organic societies where individual needs are subordinate to those of the community. Justification of individual needs being prioritised over those of a community, will allow for critical evaluation by learners.

Most Afghani men and especially members of the Taliban are depicted as violent in the trilogy. There are many incidents where women and girls are beaten when not adhering to strict rules about dress code or when unaccompanied by male members of their families. However, Ellis provides a more realistic portrayal when she includes stories of ordinary, non-violent Afghani men. Parvana reads a letter to a Talib 
that is addressed to his dead wife. He is overcome with emotion: 'She saw a tear fall from his eye' (Ellis 2000:73). Thus, the more humane counterpart to the cruel, misogynistic males reminds the reader that no cultural group can be stereotyped. However, learners should be critical of how 'good' and 'bad' males are portrayed in the trilogy. Parvana's father has been educated in the West and adopted many Westernised ways. His wife is allowed to follow a career and he encourages his daughters to seek an education. He stands in sharp contrast to the uneducated Taliban soldiers who are 'unpredictable, violent and illiterate' (Bean \& Harper 2007:26).

On a more political level, learners may be prompted to research the history of the rise of the Taliban. Brief mention is made at the back of The breadwinner in an author's note: 'The Taliban militia, one of the groups that the US and Pakistan once funded, trained, and armed, took control of the capital city of Kabul' (Ellis 2000:162). The author's note in Mud city reads:

Into this mess came the Taliban. These were originally boys whose parents had been killed in the war with the Soviets. They were taken out of Afghanistan and trained in special military schools in Pakistan (funded by the Pakistan and American secret police) to form an army that would eventually take over the country. (Ellis 2003:155)

The history of the rise of the Taliban is extremely complex and not as unambiguous as believed by some. This complexity is perhaps the reason for the superficial references above. Functionality of research on the history of the rise of the Taliban may depend on the age and ability of learners to understand complex political situations. Rubin (2002) in an article entitled: 'Who is responsible for the rise of the Taliban?' argues that understanding the roots of the Afghan civil war involves a complex story that started prior to the Russian invasion. Rubin (2002) suggests that the reason for the rise of the Taliban lies in the ethnic, linguistic and religious diversity of the country. This diversity on so many levels may, however, provide food for critical questions. Learners may be prompted to argue whether diversity may be a guarantee for conflict, and whether more homogeneous societies are less susceptible to racial, cultural and spiritual strife. A question related to social justice may be: How sovereign are certain countries when they can be invaded by more powerful countries?

\section{The girl in the tangerine scarf- Mohja Kahf}

The story of Khadra Shamy, a Syrian immigrant growing up in Indiana in the 1970s, unfolds in this novel. She is part of a close-knit Muslim family who try to uphold cultural and religious values by making very clear distinctions between what is Halal (allowed) and Haram (prohibited). The struggles of immigrants - specifically Arabs and Muslims in America - are represented through Khadra's life. These struggles concern anti-Muslim sentiments as well as ignorance and humiliation because of veiling practices.
Khadra is desperately searching for her own identity and she needs to find a balance between her Muslim/Islamic identity and being American. Kahf not only addresses racial discrimination between Americans and Muslims, but also among the very diverse Muslim communities. She does not avoid exposing the racist view Khadra's mother has of Americans in general. What is most significant for this article is Kahf's portrayal of the ambivalences associated with the veil. Toossi (2014:647) comments that the novel is about identity, displacement and home in the context of the life experiences of Muslim immigrant women, and that the veil is 'a key element in representing these relations'. I intend to use similar and other questions on Kahf's novel within a critical literacy paradigm. Learners may compare Ellis's The breadwinner trilogy with Kahf's The girl in the tangerine scarf when answering similar and other questions on both novels. The way knowledge about Muslim girls/women is constructed in both works may be compared.

\section{How is the Muslim female portrayed on the cover of the novel?}

The cover shows an image of a woman wearing a tangerine coloured scarf around her head and shoulders. This colour is associated with joy, being uninhibited and extroverted. She is also wearing what looks like a black t-shirt and blue jeans. The woman looks serene and content while leaning lightly against a wall in the background. Alkarawi and Bahar (2013:102) comment that this image communicates many explicit messages concerning Muslim women/Islam and how they are seen by the West. This image seems to disprove stereotypical portrayals of Muslim girls and women as dressed only in black, covered completely, and being oppressed. The letters in the title are multicoloured and may be seen as strengthening Kahf's message of diversity within Islam and specifically veiling practices. The tangerine scarf is described in the novel as being made of 'tissuey silk fabric' which can be pulled through a ring (Kahf 2006:293). This flowing, silky scarf is draped in such a way as to emphasise how comfortable and unrestrictive it is to the one wearing it. The entire image suggests confidence, and the few loose strands of hair sticking out from under the scarf also deconstruct conventional Western images about rigidity regarding the display of hair.

\section{What is written about veiling practices on the back cover?}

The reader learns that Khadra is at the 'crossroads of bad polyester and Islamic dress codes' (Kahf 2006). Nothing positive or negative is said about veiling practices, but Kahf refers to Islamic dress codes in the plural. Thus, she focuses the attention of the reader on the fact that ways of dressing within Muslims communities are varied, and not uniform as usually understood. The word 'crossroads' refers to the clash between Western secularism and Islamic spirituality. Khadra figuratively comes to the crossroads in her life when she has to reconcile her Muslim/Arab identity with being American. 
Khan et al. (2007:392) concur that Khadra's hybridity of being Syrian, American and Muslim at the same time allows her to be aware of the obstacles and possibilities of these locations and identities. This assimilation into a foreign, or in this case Western culture, is a matter that will become a reality for thousands of refugees at this moment fleeing war and prosecution from various Middle-Eastern countries and streaming into Europe. Learners should critically reflect on the complexity of merging two cultures. Through Khadra's journey of self-discovery, learners may catch a glimpse of the difficulty of reconciling one's culture with that of another. Khadra's quest into herself and her Muslim/Islamic identity is reflected in her various veiling practices or lack thereof. She reflects:

How veiling and unveiling are part of the same process, the same cycle, how both are necessary; how both light and darkness are connected moments in the development of the soul in its darkroom. (Kahf 2006:309)

The element of choice whether to veil or not is strongly evident in her words.

\section{What discriminatory practices are evident in the novel?}

Khadra gradually comes to see the ugly face of racism, not only from fellow Americans but also within the diverse Muslim communities. One particular disturbing incident is when Khadra is bullied by the Lott boys of the neighbourhood. They target her veil and make no secret of their utter aversion to it through their derision: 'Look, raghead's got hair under that piece of shit' (Kahf 2006:124). Another is when Zuhura's henna is held in the community room of The fallen Timbers Townhouse complex, and the clubhouse is trashed by clan members who leave obscene messages: 'RAGHEADS DIE. They were signed: KKK, 100\% USA' (Kahf 2006:82). Learners should be prompted to make connections to their own situations. Many countries are plagued by anti-Muslim sentiment at the moment. Kahf also addresses the very heterogenic spectrum of Muslims and their own prejudices among one another. Khan et al. (2007:391) assert that Kahf's novel is 'unapologetic and uncelebratory in its presentation of American Muslims'.

Khadra's parents have a very rigid belief system. Khadra slowly becomes aware that the ideal of the Dawah Center (where her parents work) of 'no racism in Islam' is just a smokescreen of denial that frustrates any efforts to 'deal with the prejudices' that exist among Muslims (Kahf 2006:137). Eyad, Khadra's brother, is infatuated with Maha, an Arab Muslim girl, who: 'had impeccable character, was active at the mosque, and wore flawless hijab with not a hair showing' (Kahf 2006:138). When Eyad requests Wajdy, his father, to consider proposing on his behalf, Wajdy's reaction is: 'But for heavens' sake, she's black as coal!' (Kahf 2006:139). Bitsy, Khadra's roommate, whose Iranian name was actually Fatima-Zahra Gordafarid before she changed it (not to be associated with Muslims), immediately judges Khadra when she sees her the first time in hijab: 'you're not one of those fanatics, are you?' (Kahf 2006:363). Kahdra's friend Chrif, who regards himself as a secular Muslim, equates Islam with barbaric practices: 'If you believe in Islam you have to believe in cutting off hands and stoning and shit' (Kahf 2006:343). These words confirm the stereotypical view held by many (including Muslims themselves) that the veil is of necessity a symbol of fanaticism. The constant conflict between Sunni, Shia and Suffi Muslims is also alluded to in Kahf's novel. Mention is made of Muslims in Iran rallying for change and removal of the Shah. Most people at the Dawah Center read The Forerunner to be kept up to date about events in Iran. Khadra comments that everyone at the Dawah Center 'believed that an Islamic state and an Islamic society was, or should be, the hope of every believing Muslim today' (Kahf 2006:62). How ironic that precisely because of this desire, fundamentalism is responsible for the dire situation in countries like Syria and Iraq. Khadra's father poses the question: 'But if Iranian Muslims made an Islamic state, would that count, being Shia?' (Kahf 2006:62). Thus he emphasises the ideological differences within Islamic religious groups.

Those being more liberal are also regarded with disgust by more conservative Muslims. Mention is made of the Mishawaka Muslims, who had 'mixed American things in with Islam', and who 'needed a refresher course in real Islam', and who did shocking things in the mosque, like 'play volleyball with men and women together' (Kahf 2006:103). Khadra is completely disillusioned with her cousin's Saudi Arabian male friends when she visits the country and is harassed. Alkarawi and Bahar (2013:103) assert that Khadra and her cousin's actions rupture 'the boundaries between veiled and unveiled Muslim women and destabilises a dichotomy between veiled and unveiled, assumed to be fixed'. These males just assume that because Khadra is from America, she refrains from wearing a veil there, and that she is available sexually. Toossi (2014:640) comments that the Muslim woman whether veiled or not 'appears as always already improperly covered'. In other words, in certain cases she can be punished for wearing a veil and in others for not wearing one. The possibility of being judged is always present.

Many of Khadra's prejudices are deconstructed when she meets Joy and her family who belong to the local Sufi community. Joy's next-door neighbour Im Lifty makes such a profound impression on Khadra with her sweet, homely, familial ways that she is forced to engage in introspection:

What other homes of similar sweetness and joy had they passed by all these years, insisting as they did on their separateness and specialness, then? What a waste. Something started to unravel in Khadra there in the kitchen, bringing her almost to the point of secret tears. (Kahf 2006:189)

Kahf exposes the racism against Americans in no uncertain terms. Much of this is seen through the actions and words of Ebtehaj, Khadra's mother. Khadra recalls how her mother 
used to do the laundry twice for fear of being contaminated by dirty laundry of Americans who 'didn't care about impurities' (Kahf 2006:4). Ebtehaj made sure her children did chores and 'didn't turn into lazy American children' (Kahf 2006:21). She does not approve of Alice, an American girl in the neighbourhood, and asserts that 'generally speaking Americans cussed, smoked, and drank [...] dated and fornicated and committed adultery' (Kahf 2006:68). Ebtehaj epitomises a Muslim immigrant who refuses to assimilate into the culture she moves into. This fact provides for another critical point of discussion: to what extent should immigrants integrate? Ebtehaj uses the Bosnia Herzegovina debacle to confirm her rigid belief that Muslims cannot be friends with non-Muslims:

[...] they've lived with the kuffar [an Arabic derogatory term for non-Muslims] of their land, taking them for friends and even marrying them, and still the kuffar, in the end, turn on them. (Kahf 2006:382)

She makes an outrageous statement that 'Muslims must become strong again in the world, and get nuclear arms, and depend on themselves' (Kahf 2006:382). This statement is indicative of the indoctrination of young Muslims by their parents and those recruiting members for fundamentalist groups. Learners need to reflect on the reasons why young people, Muslim and non-Muslims, join ISIL and why they endorse their ideologies. Khadra describes American white men in very stereotypical and unflattering ways: '[...] blotchy pink type of face that white men have', and 'Why didn't American men grow beards like decent folk?' (Kahf 2006:29). Kahf also touches on the belief that many Muslims have that those belonging to other religious groups are infidels: 'The Americans were the white people who surrounded them, a crashing sea of unbelief' (Kahf 2006:29).

Khadra comes to a profound insight towards the end of the novel. She comes to realise that the Muslim way of faith is not the only acceptable way: 'Maybe divine law manifests in many ways in the world. Maybe you don't always have to have it set in stone as the so-called "Islamic lifestyle"' (Kahf 2006:402). Toossi (2014:650) observes that Kahf 'highlights intersections of power and knowledge', as it is the dominant Muslim group that 'holds the exclusive right to define the parameters' of what is right and wrong. Khadra realises in the end that life is more about love and less about doctrines and rituals.

\section{How are veiling practices presented?}

Learners may focus on whether the veil is seen in a positive or negative light, as well as how Khadra's own growth and search for identity is depicted through her relationship with the veil. The initial excitement of 'being hijabed' as a young girl is soon shattered when Khadra realises that the veil is an object of revulsion for some Americans as is evident from the incident with the Lott boys. Alkarawi and Bahar (2013:102) argue that the veil is viewed in the West as a 'fetish sign of oppression in the eyes of hegemonic discourse'. A few events, such as the hostage crisis of American citizens in the US embassy in Iran, and discriminatory practices of those having an aversion towards Muslims in her neighbourhood, drive Khadra as a teenager towards taking a more radical stance in her veiling practices. Khadra starts 'donning black headscarves with a surge of righteous austerity' (Kahf 2006:149) and 'radical Islam was her James Dean' (Kahf 2006:152). Toossi (2014:649) observes that this adoption of a black veil destabilises Khadra's identity as American, as its colour denotes 'allegiance to an extremist militant ideology'. She is barred from praying at the mosque in Mecca and comes to realise that Muslim women in America have more freedom than in the Middle East. This fact is confirmed by Wajdy, Khadra's father: '[...] here inside America, there are many good qualities. Law and order, cleanliness, democracy, freedom to work and honestly seek the provision of the Lord' (Kahf 2006:144). Khadra soon enters a phase in which she 'thirsted now to study traditional Islamic heritage' (Kahf 2006:194) and during which the treasures of Qu'ran recital were unlocked for Khadra (Kahf 2006:197). This phase does not last for long though, as she becomes disillusioned with Muslim gender discrimination when she is not allowed to enter a Quranic recital competition because she is a woman. Ironically Khadra makes the decision to shed her veil in Syria and realises that one can display modesty in the way one carries oneself without the necessity of being veiled. Kahf echoes Islamic feminists here by placing emphasis on the fact that modesty can be displayed in many ways. What is important in Khadra's constant veiling and re-veiling is that she is finally not influenced by either Islamic patriarchal or Western secularist ideas. Toossi (2014:652) comments that Khadra's final act of adopting the veil again is 'not contingent upon imposing patriarchal discourses'. She elects the hijab at the end because she wants to, and because she feels it is an inseparable part of her, connecting her to her culture and people: 'It is an outer sign of an inner quality she wants to be reminded of, more often than she could manage to remind herself without it' (Kahf 2006:425). Learners will become aware that culture can be an individual choice and is not always a result of an act of coercion.

\section{Conclusion}

The mass media, in the form of TV, newspapers and magazines as well as digital media, are powerful tools for instilling certain perceptions about cultural groups, and in the context of this article, specifically about Muslims and Islam. One-sided portrayals of fundamentalists marring the image of Muslims and Islam may lead to Western nations forming a monolithic idea of Muslims and Islam. Stereotypes are reinforced when particular images are repeated and others are omitted. The global youth has to be aware of its dangers on the one hand, and on the other hand, the danger of stereotyping. I argue that literature, and specifically the genre of the novel, may be used to broaden learners' views of ideological and spiritual differences. Knowledge construction may be questioned through critical literacy questions. Martino and Rezai-Rashti (2008:423) argue that 'more informed perspectives on the historically situated practices 
of veiling are needed to challenge Imperial fictions and the politics of truth-making about Islam'. As already established, the veil is mostly seen as a symbol of oppression by many Westerners. The observation of various veiling practices indicates that Muslim societies are not homogeneous, and this unpacking of the manifold meanings of the veil may be agential in leading to a better understanding of the cultural diversity within Muslim cultures in general. Learners may also grasp that clothing, and by implication the veil, may become a powerful political and social tool (Hoodfar 2003). They will be confronted with their own assumptions about those different from themselves, and some fallacies, stereotypes and untruths may be dispersed. By examining how cultures and cultural practices are depicted, learners may come to see that when certain cultures are dominant they come to be regarded as the norm. A comparison between how Muslim girls/women are presented in the novels may prompt questions about texts privileging some views, beliefs and values over others. Furthermore, the aim of teaching these multicultural texts should not, again, be simply to instil tolerance, because as Nieto (2010:251) points out tolerance implies that 'differences are endured, not necessarily embraced'. Hale (2007:189) refers to the novel reader's 'free submission' to the 'hailing' performed by the novel as a necessary condition for achieving social diversity, 'a training in the honouring of Otherness' which makes novel reading a 'crucial pre-condition for positive social change'. This article does not argue that the studying of multicultural texts, or a better understanding of veiling practices, is a quick remedy for the existing ills in society, but these are starting points within a fictional environment powerful enough to stir critical thinking.

\section{Acknowledgements Competing interests}

The author declares that she has no financial or personal relationships which may have inappropriately influenced her in writing this article.

\section{References}

Aaftaab, N.G., 2005, '(Re)defining public spaces through developmental education for Afghan women', in G. Falah \& C. Nagel (eds.), Geographies of Muslim women: Gender, religion, and space, pp. 44-67, The Guilford Press, New York.

Abulughod, L., 2000, Veiled sentiments: Honor and poetry in a Bedouin society, University of California Press, Oakland, CA.

Ahmed, L., 1992, Women and gender in Islam: Historical roots of a modern debate, Yale University Press, New Haven, CT.

Ahmed, L., 2005, 'The veil debate - Again', in N. Fereshteh (ed.), On shifting ground: Muslim women in the global era, pp. 160-170, Feminist Press at the City University Press, New York.

Alkarawi, S.T. \& Bahar, I.B., 2013, 'Negotiating liminal identities in Mohja Kahf's The girl in the tangerine scarf', International Journal of Applied Linguistics \& English

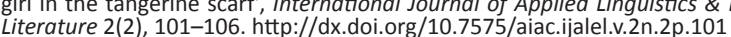

Al Qutami, M.Y., 2009, 'Feminist resistance in contemporary American women writer of colour: Unsettling images of the veil and the house in Western culture', PhD thesis, Department of English, Indiana University of Pennsylvania.

Ameri, F., 2008, Sacred spaces in contemporary English literature: Muslim contributions, viewed 19 October 2015, from http://hgsoconference.curtin.edu. $\mathrm{au} /$ previous/2008proceedings.cfm

Apple, M., 1996, Cultural politics and education, Teachers College Press, New York.

Baer, A.L. \& Glasgow, J.N., 2010, 'Negotiating understanding through the young adult literature of Muslim cultures', Journal of Adolescent and Adult Literacy 54(1) 23-32. http://dx.doi.org/10.1598/JAAL.54.1.3

Bean, T.W. \& Harper, H.J., 2006, 'Exploring notions of freedom in and through young adult literature', Journal of Adolescent and Adult Literacy 50(2), 96-104. http:// dx.doi.org/10.1598/JAAL.50.2.2
Bean, T.W. \& Harper, H.J., 2007, 'Reading men differently: Alternative portrayals of masculinity in contemporary young adult fiction', Reading Psychology 28, 11-20. http://dx.doi.org/10.1080/02702710601115406

Bouleanu, A., 2013, Fatema Mernissi, Nawal El Saadawi, and Amina Wadud: A survey of Islamic feminism, viewed 27 August 2016, from https:// geostrategicandgeopoliticalstudiesinstitute.wordpress.com/2013/03/14/fatemamernissi-nawal-el-saadawi-and-amina-wadud-a-survey-of-islamic-feminism-by/

Brown, W., 2008, Regulating aversion: Tolerance in the age of identity and empire, Princeton University Press, Princeton, NJ.

Dean-Ruzicka, R., 2012, 'Combating hate through young adult literature', Journal of Hate Studies 10(1), 199-221.

Ellis, D., 2000, The breadwinner, Oxford University Press, Oxford.

Ellis, D., 2002, Parvana's journey, Oxford University Press, Oxford.

Ellis, D., 2003, Mud city, Oxford University Press, Oxford.

Hale, D., 2007, 'Fiction as restriction: Self-binding in new ethical theories of the novel', Narrative 15(2), 187-206. http://dx.doi.org/10.1353/nar.2007.0010

Henry, P. \& Middleton-Kaplan, R., 2010, 'Using literature to teach peace', Peace Research 42(1/2), 142-166.

Hesford, W.S. \& Kozol, W., 2005, 'Introduction', in W.S Hesford \& W. Kozol (eds.), Just advocacy: Women's human rights, transnational feminisms, and the politics of representation, pp. 1-28, Rutgers University Press, London.

Hoel, N., 2013, 'Sexualising the sacred, sacrilising sexuality: An analysis of public responses to Muslim women's religious leadership in the context of a Cape Town mosque', Journal for the Study of Religion 26(2), 25-41.

Hoodfar, H., 2003, 'More than clothing: Veiling as an adaptive strategy', in S.S. Alvi, H. Hoodfar \& S. McDonough (eds.), The Muslim veil in North America: Issues and debates, pp. 3-40, Women's Press, Toronto, ON.

Kahf, M., 2006, The girl in the tangerine scarf, Public Affairs, New York.

Khan, S., Bhimani, S., Watt, D.P. \& Farhoumand-Sims, C., 2007, 'Book reviews', Intercultural Education 18(4), 389-395. http://dx.doi.org/10.1080/14675 980701605394

Lewison, M., Flint, A.S. \& Van Sluys, K., 2002, 'Taking on critical literacy: The journey of newcomers and novices', Language Arts 79(5), 382-392.

Lynch-Brown, C.G., Tomlinson, C.M. \& Short, K.G., 2014, Essentials of children's literature, 7th edn., Pearson Education Limited, Essex.

Martino, W. \& Rezai-Rashti, G.M., 2008, 'The politics of veiling, gender and the Muslim subject: On the limits and possibilities of anti-racist education in the after-math of September 11', Discourse: Studies in the Cultural Politics of Education 29(3), 417-431. http://dx.doi.org/10.1080/01596300802259178

Mazumdar, S., 2001, 'Rethinking public and private space: Religion and women in Muslim society', Journal of Architectural and Planning Research 18(4), 302-324.

McLaren, P., 2009, 'Critical pedagogy: A look at the major concepts', in A. Darder, M. Baltodano \& R. Torres (eds.), Critical pedagogy reader, 2 nd edn., pp. 61-83, Routlegde, New York.

Najmabadi, A., 2006, 'Gender and secularism of modernity: How can a Muslim woman be French?', Feminist Studies 32(2), 232-255. http://dx.doi.org/10.2307/20459085

Nodelman, P. \& Reimer, M., 2003, The pleasures of children's literature, 3rd edn., Allyn and Bacon, Boston, MA.

Nieto, S., 2010, Language, culture, and teaching: Critical perspectives, 2nd edn., Routledge, New York.

OED (Oxford English Dictionary), 2015, 'Tolerance', viewed 16 October 2015, from http://www.oed.com.nwulib.nwu.ac.za/search?searchType=dictionary\&q=tolera nce\&_searchBtn=Search

Plaisance, P.L., 2002, The journalist as moral witness: Michael Ignatieff's pluralistic philosophy for a global media culture, viewed 20 November 2015, from http:// jou.sagepub.com/content/3/2/205.full.pdf

Rondganger, L. \& Govender, P., 2004, 'Wrangle over headscarf at Johannesburg school', The Star, 23 January, viewed 20 November 2015, from http://www.iol. co.za/news/south-africa/wrangle-over-headscarf-at-sa-school-121555

Rubin, M., 2002, Who is responsible for the Taliban? Middle East review of international affairs, viewed 12 October 2015, from http://www.michaelrubin.org/1220/whois-responsible-for-the-taliban

Said, E.W., 1979, Orientalism, Vintage Books, New York.

Said, E.W., 1993, Culture and imperialism, Vintage, London.

Said, E.W., 1997, Covering Islam: How the media and the experts determine how we see the rest of the world, Vintage, London.

Saltman, E.M. \& Winter, C., 2014, 'Islamic state: The changing face of modern jihadism', viewed 25 August 2016, from https://web.archive.org/web/ 20150226115714/http://www.quilliamfoundation.org:80/wp/wp-content/ uploads/publications/free/islamic-state-the-changing-face-of-modern-jihadism.pdf

Sensoy, O. \& Marshall, E., 2009, 'Save the Muslim girl', Rethinking Schools 24(2), viewed 15 August 2015, from http://www.rethinkingschools.org/archive/24_02/ 24_02_muslim.shtml

Sensoy, O. \& Marshall, E., 2010, 'Missionary girl power: Saving the "third world" one girl at a time', Gender and Education 22(3), 295-311. http://dx.doi.org/10. 1080/09540250903289451

Shor, I., 1999, 'What is critical literacy?', Journal of Pedagogy, Pluralism and Practice $1(4)$, viewed 10 November 2015, from http://www.lesley.edu/journal-pedagogypluralism-practice/ira-shor/critical-literacy/ 
The Washington Post, 2001, 'Laura Bush on Taliban oppression of women', viewed 16 March 2015, from http://www.washingtonpost.com/wp-srv/nation/specials/ attacked/transcripts/laurabushtext_111701.html

Toossi, K.Z., 2014, 'The conundrum of the veil and Mohja Kahf's literary representation of hijab', Interventions: International Journal of Postcolonial Studies 17(5), 640-656. http://dx.doi.org/10.1080/1369801X.2014.984617

Wise, C., 2009, Derrida, Africa and the Middle East, Palgrave Macmillan, New York.
Woodlock, R., 2000, 'Veiling and Hijab as understood by Muslim feminists: Excerpted from "Muslim feminists and the veil- to veil or not to veil- is that the question", viewed 25 August 2016, from, http://www.irfi.org/articles/articles_301_350/ veiling and hijab as understood.htm

Zakaria, F., 2014, 'Let's be honest, Islam has a problem right now', The Washington Post, 9 October, viewed 10 October 2015, from https://www.washingtonpost.com/ opinions/fareed-zakaria-islam-has-a-problem-right-now-but-heres-why-bill-mah 